DOI: 10.31866/2617-2674.4.1.2021.235071

UDC 791.635-051:792.028.3

\title{
USING OF HUMAN BEHAVIOR MANNERS IN THE PROCESS OF A FILM ACTOR PREPARING FOR A ROLE
}

\section{Olena Levchenko ${ }^{1 a}$, Olha Pasichnyk ${ }^{2 a}$}

${ }^{1}$ Doctor of Sciences in Philosophy, Senior Researcher, Professor of Television Journalism and Acting Department; e-mail: levch@bigmir.net; ORCID: 0000-0002-0739-9777

${ }^{2}$ Master's Student at the Television Journalism and Acting Department; e-mail: pasechnik-olya@ukr.net; ORCID:0000-0002-7438-8517

${ }^{a}$ Kyiv National University of Culture and Arts, Kyiv, Ukraine

\section{Keywords:}

behavioural manner; movie actor; movie role; character; mimics; score role; dramatic identification; demonstration; visualization

\begin{abstract}
The purpose of the research is to reveal the features of the use of a human behaviour manner in the process of preparing a cinema actor preparing for a role. The research methodology is based on the principles of descriptive, comparative, cultural and artistic methods, the method of observation and experiment, in addition, individualizing and social and psychological approaches are applied during the study of the psycho-physiology of acting through the analysis of the behaviour in the process of individual human capabilities disclosing. The scientific novelty of the research is that the workmanship of the acting game is analyzed through the allocation of a visual demonstration of the manner of behaviour from the inner senses of the character for the first time. Conclusions. The research has shown and analyzed the use of human behaviour in the process of film actor preparing for his/her role. It has been found that the accumulated experience of body movements enriches the repertoire of acting, reduces the risk of the hero emotional state over the inner freedom of a professional actor. Accordingly, with the explored information, the main point here is that impersonation for a character is demonstrating by the simplest properties of human behaviour.
\end{abstract}

For citation:

Levchenko, O. and Pasichnyk, O. (2021). Using of human behavior manners in the process of a film actor preparing for a role. Bulletin of Kyiv National University of Culture and Arts. Series in Audiovisual Arts and Production, 4(1), pp.35-42.

\section{Problem Statement}

The principles of the study of an organic way of the actor's existence in the frame and on stage are the keys to the successful creation of any artistic image of screen and theatre arts. With the help of carefully studied external changes, the actor forms his own arsenal of means for expressing the feelings and emotions of the character. It is also necessary to accumulate a technological base that in- 
cludes the ability to own your body, facial expressions, voice and speech apparatus.

In the modern world, it is difficult for people to control their emotions, to feel free under different circumstances. This leads to internal clamps, which can be observed not only in constrained movements but also in facial expressions and the nature of pronunciation. The actor's skill is aimed at mastering the above skills and developing the psychophysiological aspects of a person. A film actor who can control his/her mood and behaviour will find the right way to discover the creative "I", which will affect the further organic disclosure and improvement of the image of the on-screen character.

The problem of preparing a film actor for the role will be urgent as long as there is screen art. The task of the actor is not only to attract and draw attention to the action that takes place on the screen but also to create favourable conditions against which the moviegoer will feel catharsis.

This article highlights and analyzes the most important techniques that a film actor should use during a masterly reincarnation.

\section{Recent research and publications analysis}

It should be said that the specifics of preparing a film actor for the role increasingly attracts the attention of not only scientists but also professional film actors.

V. Meyerhold (1968, p.316) during the study and analysis of the elements of cinema emphasized the difference between the specifics of the film actor's game and the theatre actor. M. Chekhov (1986, p.267) in his revisions notes the artist's creative individuality: he denies the frank experience of an emotional state, offers to simulate movements. V. Demeshchenko (2011, p.147) in his article draws attention to the concept of a conditional actor's game, based on the principles of grotesque proposed by V. Meyerhold. The book "Acting. American School" describes the study of $M$. Chekhov about the feelings of the actor during the performance of the role (Bartow, 2015, p.187). Vera Polishchuk and Elvira Sarabian (2014, p.2) collected a large number of pieces of trainings offered by famous directors such as Stanislavsky, Meyerhold, Chekhov, Tovstonogov.

\section{Presentation of the main material}

The manner of the actor's behaviour is directly related to his internal state during a certain period performance of the film role. It makes it possible to reveal the character and cover many characteristic features in a short period. The act ing task is to demonstrate the external features of the character as brightly and clearly as possible to the audience, keep a wide range of attention and prevent the possibility of incorrectly responding to changes in the relationship of partners in the game. For film actors, it is important to carefully study each movement of their body. Trying to explore the nature of its primary occurrence, we rely on physical indicators, which are one of the most important components in the creative activities of visual art.

Attempts by the famous Soviet actor and theatre director $\mathrm{V}$. Meyerhold to resist the system of K. Stanislavsky were based on the psychological level of emotional experiences (Demeshchenko, 2011, p.147). He proposed his specifics of acting, closely related to the principle of grotesque (Demeshchenko, 2011, p.151). In 
our understanding, this principle will not allow us to adopt the deep experiences of the hero of the work due to the excessive demonstration of the proposed emotional state.

One of the first researchers of the acting technique is M. Chekhov. He emphasized that the actor working on the role should not experience the character's feelings as his own and perceive the circumstances that are around. The centre of attention should be precisely the artistic image of the hero, and not internal worries (Bartow, 2015, p.187).

The actor should be aware of the nature of the stage feeling: not to feel, but to sympathize with the created artistic image (Chekhov, 1986, p.267). An expressive demonstration of the character's behaviour includes creative feelings in the actor, harmoniously combining an external manner with an internal emotional state (Chekhov, 1986, p.231).

The very first and main property that a film actor should have is body flexibility. In order to develop such a property of the body some special training for the development of plasticity and the liberation of the human body has been opened (Polishchuk and Sarabian, 2014, pp.2139). Based on the proposed methods, internal freedom is formed, the liveliness of perception develops and hidden creative makings of a person are revealed. Stanislavsky is the first inventor who developed a technique for removing bodily clamps from actors. Through bodily exercises and the execution of creative etudes, he tried to discover creative, uncharacteristic actions in the human body for everyday life (Stanislavsky, 2009, pp.18-24).

The second structural element that the film actor should ably control is facial expressions. Before going to the set of the actor can sometimes observe strange behaviour: he/she suddenly begins to grimace, inflate his cheeks, extend his tongue, staring his eyes and raise his eyebrows. This is the method is considered effective for pre-relaxing the face, which in the future will allow you to feel each muscle.

The third component of the film-acting tool is a voice, thanks to which you can track the inner state of the hero, follow the intonation and understand the sincerity of the real feelings of the on-screen character. Given such acting properties, the study of the above components is especially valuable while working on the role.

Consider and compare the manner of acting in two different situations: creating an image for the film industry, that is working on camera and creating a stage image for playing in the theatre. Each actor must have good physical training, which will allow at any moment to be able to quickly rebuild and adapt to given changes.

In the theatre, an integral part of the creative process is body warm-up, in order to widely demonstrate movements, not overstretch and quickly respond to changes in events. The theatre has a large space and a significant number of spectators who do not allow the actor to be unnoticed. Acting as a puppet, most movements of which are already thought out in advance and do not allow doing otherwise, he/she must use a wide range to express his own actions.

There are three styles of human communication - passive, aggressive, and confident. A passive actor will have a physical restriction to demonstrate his own movements. A person who has such a condition neglects his principles and interests, tries to avoid unnecessary clash- 
es and quickly leave the scene. He/she does not have his/her own arguments for expressing an opinion, which is why he/ she agrees with the contemplation of the people who surround this person.

Due to visually reflect the behaviour of an aggressive character, sharp confident steps, strict even posture, as well as a high raised head, will be characteristic signs. In order to cause noticeable discomfort to his partner in the frame, the actor is forced to carry out a number of provocative gestures that will make the viewer believe in the authenticity of emotional tension.

A confident hero is one who has his own position and defends it. He does not offend others but also does not allow him to convince himself otherwise.

During filming, the actor needs to adapt and be able to otherwise use the manner of the character's external display. The shooting of the frame has limited space, so the film actor must carefully approach the process of reproducing movements. This will allow the camera to clearly capture them and pay attention to themselves. This aspect of the game requires the actor to be able to perfectly own his body and skillfully manage it. During the demonstration of certain movements, the actor must remember that he works on the camera, and therefore do not perform them too quickly so that the viewer has time to understand, evaluate and accept these gestures.

Aggressiveness is a type of human behaviour that can provide the actor with a large reserve of various movements and gestures, which in the future will help to understand roles more deeply and insightfully. In each individual who is adopted by this state, natural reactions to external manifestation are reflected differently. A film actor must choose such characteristic properties of aggressive behaviour that will be inherent in his nature. To look quite natural and organic in the frame, he uses his own luggage of physical movements.

A confident film actor does not expect an accidental combination of circumstances but acts independently in order to get what he wants. The determination, manifestation of initiative and the ability to present themselves correctly are widely demonstrated by the common intentions and actions of the film hero. The camera captures the initial position of the actor, which allow the viewer to perceive the general state and manner of behavior of the character.

To convey a full-fledged simulated image during filming and on the stage of the theatre, the actor should analyze facial reactions. In the theatre, it is allowed to exaggerate the reaction to certain circumstances in order to convey a certain image to the viewer more clearly and more interesting. Therefore, the task of the actor is to observe the external differences in facial expressions during a change in the relationship between the characters of the work for further study, fixation and storage in memory of acquired visible variable features. Galina Menshikova (2009, pp.27-78) describes a number of facial muscle exercises. An actor who performs them can feel and control his physiognomy. Facial expressions help to create the necessary image, complementing other visible characteristics of the character. As a result, in all universities, where film actors study, great attention is given to work on conscious face grimace, which helps to control the surge of emotions during acting.

In everyday life, a person is controlled by an emotional state that intercepts his breath: be it ordinary laughter or sob- 
bing. The film actor has the opposite one External reflections of facial reactions should be expressive, but sustained and delicate so the viewer can believe in the sincerity, authenticity of acting. During the shooting, the actor should be completely relaxed and reassured, because the least unplanned facial tension in the frame looks unnatural and fake. Due to the characteristic external manifestations of the film actor during the expression of such emotions: anger, joy, fear, suffering, bewilderment, contempt.

Anger is a negative emotion that can provoke a person to carry out rash actions in a tense state. This reaction causes dissatisfied feelings, so it can be accompanied by unusual actions and changes that can significantly affect the vital activity of the human body (Efimov, 2009, p.533). For the actor to visualize this type of emotion, it is necessary to practice in advance, to put in memory elements of a detailed analysis of this mimic reaction.

Joy is a pleasant and benevolent emotion that increases a person's mood, enhances his vital activity and general physical activity (Efımov, 2009, p.533). It meets human needs and ensures the successful implementation of goals and plans. The film actor can demonstrate this condition through a pleasant facial expression, without undue tension.

Fear is an unpleasant feeling that makes a person suffer and feel uncomfortable (Efimov, 2009, p.533). It can inspire long-term phobia (mental illness), cause a state of depression and even paralyze the life of the human body. Anxiety appears sometimes and causes inadequate behaviour.

Suffering is an emotion that arises after an annoying situation or unpleasant event (loss, defeat, failure) and causes an imbalance in the human body, suppresses her condition, due to which she has a pronounced character (Efimov, 2009, p.533). The film actor needs to simulate the expression of a person's face with the help of his own skills to quickly relax facial expressions and manage her.

Bewilderment is an unexpected reaction caused by the body due to a sharp, unexpected, instantaneous change in the nature of behaviour to a specific situation (Efimov, 2009, p.534). It is very difficult to catch and fix it. It comes and goes quickly. People show this emotion in different ways. An actor performing a movie role must rely on his own experience in reproducing this reaction, so as not to exaggerate with pretending and copying it from another person.

Contempt (neglect) is an emotional reaction of a person aimed at a certain object, which also deserves attention (Efimov, 2009, p.534). It happens when the actor has the right to build on at the time of analysis of the character's facial expressions for a masterful approach to the performance of a movie role.

The next component that helps the film actor express his opinion and inform the viewer about the further development of events is the voice and the correct ability to intonate him. Voice is one of the most important professional tools that a film and theatre actor must possess. Voice staging is necessary for the correct, clear and qualitative pronunciation of the text, its intonation. For speech technique, this is the main requirement that develops the plasticity of the voice, its sound and correct diction. To convey the main idea of the screenwriter, the actor is advised to familiarize himself with the details of the written in advance, prioritize the course of events and, starting from them, build the voice score of the role. That is, to 
penetrate the text, phrases, words in order to work as virtuoso as possible with it: to express thoughts creatively and inspired, to give dialogue various intonation shades, to emphasize the most important thing for revealing emotional content. The actor improves his voice and language so there is no monotony in the performance of the movie role. He has to interesting in submitting the text with the smallest intonation colour and keep the viewer's attention until the end of the screen or theatrical action.

\section{Conclusions}

The profession of an actor has many different aspects, the study of which will help significantly expand the usual circle of attention, develop creative potential and masterfully reveal the fictional image of a screen character. In order not to expose yourself to internal experiences that characterize a certain hero of the work, it is enough to study precisely the external characteristic features that are reflected on a person during a change in relations. This path will help to avoid problems with the wrong appearance of acting feelings and build the score of the role by developing your own natural data. Due to the simplest properties of the manner of behavior, the secrets of reincarnation for visualizing the character are revealed.

The correct selection of material according to the goal helped us to compare and analyze the most famous characteristic features of using manners of human behaviour in the process of preparing a film actor for a role.

\section{REFERENCES}

Bartou, A., 2015. Akterskoe masterstvo. Amerikanskaia shkola [Acting. American School]. Moscow: Alpina non-fikshn.

Chekhov, M.A., 1986. Literaturnoe nasledie [Literary heritage]. Moscow: Iskusstvo. T. 2: Ob iskusstve aktera [On the art of the actor].

Demeshchenko, V.V., 2011. Tvorchyi syntez rezhyserskykh poshukiv Vsevoloda Meiierkholda [Creative synthesis of director's search for Vsevolod Meyerhold]. Mystetstvoznavchi zapysky, 20, pp.144-153.

lefimov, H.M., 2009. Modeliuvannia ta rozpiznavannia mimichnykh proiaviv emotsii na oblychchi liudyny [Modeling and recognition of facial expressions of emotions on the human face]. Shtuchnyi intelekt, 3, pp.532-542.

Meierkhold, V.E., 1968. Stati, pisma, rechi, besedy [Articles, letters, speeches, conversations] Moscow: Iskusstvo. Ch. 1: (1891-1917).

Menshikova, G.V., 2009. Mimicheskie uprazhneniia dlia kozhi i myshtc litca. 40 unikalnykh uprazhnenii [Mimic exercises for the skin and muscles of the face. 40 unique exercises] Moscow: AST.

Polishchuk, V. and Sarabian, E., 2014. Bibliia akterskogo masterstva. Unikalnoe sobranie akterskikh treningov po metodikam velichaishikh rezhisserov [Acting Bible. A unique collection of acting trainings based on the techniques of the greatest directors]. Moscow: AST.

Stanislavskii, K.S., 2009. Akterskii trening: uchebnik akterskogo masterstva. Rabota aktera nad soboi $v$ tvorcheskom protcesse voploshcheniia [Acting training: a textbook on acting. The work of an actor on himself in the creative process of incarnation]. St. Petersburg: Praim-Evroznak. 


\section{ВИКОРИСТАННЯ МАНЕР ЛЮДСЬКОЇ ПОВЕДІНКИ В ПРОЦЕСІ ПІДГОТОВКИ КІНОАКТОРА ДО РОЛІ}

\section{Олена Левченко ${ }^{1 a}$, Ольга Пасічник ${ }^{2 a}$}

${ }^{1}$ доктор філософських наук, старший науковий співробітник, професор кафедри тележурналістики та майстерності актора; e-mail: levch@bigmir.net; ORCID: 0000-0002-0739-9777

${ }^{2}$ магістрант кафедри тележурналістики та майстерності актора; e-mail: pasechnik-olya@ukr.net; ORCID: 0000-0002-7438-8517

а Київський національний університет культури і мистецтв, Київ, Україна

\section{Анотація}

Мета дослідження - розкрити особливості використання манер людської поведінки в процесі підготовки кіноактора до ролі. Методологія дослідження ґрунтується на принципах описового, порівняльного, культурно-мистецтвознавчого методів, методу спостереження й експерименту, крім того, застосовані індивідуалізуючий і соціально-психологічний підходи під час дослідження психофізіології акторського мистецтва через аналіз манер поведінки в процесі розкриття індивідуальних людських можливостей. Наукова новизна полягає у тому, що вперше проаналізовано майстерність акторської гри через виокремлення наочної демонстрації манер поведінки від внутрішніх почуттів персонажа. Висновки. Під час дослідження було розкрито та проаналізовано використання манер людської поведінки в процесі підготовки кіноактора до ролі. Розглянуто характерні зовнішні прояви кіноактора під час вираження емоцій (гнів, радість, страх, страждання, подив, презирство). З'ясовано, що накопичений досвід рухів тіла збагачує репертуар акторських дій, зменшує ризик переважання емоційного стану героя над внутрішньою свободою професійного актора. Висвітлено й схарактеризовано найголовніші засоби, якими повинен користуватися кіноактор під час майстерного перевтілення, адже проблема підготовки кіноактора до ролі буде актуальною доти, доки існує екранне мистецтво. На основі досліджуваної інформації виведено підсумки: через найпростіші властивості манери поведінки розкриваються секрети перевтілення для візуалізації персонажа.

Ключові слова: манера поведінки; кіноактор; кінороль; персонаж; міміка; партитура ролі; перевтілення; демонстрація; візуалізація 


\title{
ИСПОЛЬЗОВАНИЕ МАНЕР ЧЕЛОВЕЧЕСКОГО ПОВЕДЕНИЯ В ПРОЦЕССЕ ПОДГОТОВКИ КИНОАКТЕРА К РОЛИ
}

\author{
Елена Левченко ${ }^{1 a}$, Ольга Пасечник ${ }^{2 a}$ \\ ${ }^{1}$ доктор философских наук, старший научный сотрудник, профессор кафедры тележурналистики \\ и мастерства актера; e-mail: levch@bigmir.net; ORCID: 0000-0002-0739-9777 \\ ${ }^{2}$ магистрант кафедры тележурналистики и мастерства актера; \\ e-mail: pasechnik-olya@ukr.net; ORCID: 0000-0002-7438-8517 \\ а Киевский национальный университет культуры и искусств, Киев, Украина
}

\begin{abstract}
Аннотация
Цель исследования - раскрыть особенности использования манер человеческого поведения в процессе подготовки киноактера к роли. Методология исследования основана на принципах описательного, сравнительного, культурно-искусствоведческого методов, метода наблюдения и эксперимента, кроме того, применены индивидуализирующий и социально-психологический подходы во время исследования психофизиологии актерского искусства через анализ манер поведения в процессе раскрытия индивидуальных человеческих возможностей. Научная новизна заключается в том, что впервые проанализировано мастерство актерской игры через выделение наглядной демонстрации манер поведения от внутренних чувств персонажа. Выводы. В ходе исследования было раскрыто и проанализировано использование манер человеческого поведения в процессе подготовки киноактера к роли. Рассмотрены характерные внешние проявления киноактера при выражении эмоций (гнев, радость, страх, страдание, удивление, презрение). Выяснено, что накопленный опыт телодвижений обогащает репертуар актерских действий, уменьшает риск преобладания эмоционального состояния героя над внутренней свободой профессионального актера. Освещены и охарактеризованы главные средства, которыми должен пользоваться киноактер во время мастерского перевоплощения, ведь проблема подготовки киноактера в роли будет актуальной до тех пор, пока существует экранное искусство. На основе исследуемой информации выведено итоги: через простейшие свойства манеры поведения раскрываются секреты перевоплощения для визуализации персонажа.
\end{abstract}

Ключевые слова: манера поведения; киноактер; кинороль; персонаж; мимика; партитура роли; перевоплощение; демонстрация; визуализация 